\title{
Selection of fat-degrading microorganisms for the treatment of lipid-contaminated environment
}

\author{
Vilma Čipinyte் \\ Saulius Grigiškis, \\ Egidijus Baškys \\ JSC Biocentras, \\ V. Graičiūno 10, \\ LT-02241 Vilnius, \\ Lithuania
}

\begin{abstract}
To develop effective microbial agents applicable to complex technology for grease wastes utilization, a total of 124 microorganisms were screened for their ability to degrade lipidic compounds. The screening yielded five strains (UP2, F2, E13, Kl1 and N3) showing lipolytic activity and rapidly degrading sunflower and olive oil, tallow and lard. Among them, strains E13 and N3 were found to have the highest lipase activity and the more intensive rates of the degradation of saturated (palmitic and stearic) and unsaturated (oleic and linoleic) fatty acids and triglycerides containing these fatty acids. The strains were obtained from the culture collection of JSC "Biocentras" and identified as Enterobacter aerogenes E13 and Arthrobacter sp. N3. When a mixed culture of strains E. aerogenes E13 and Arthrobacter sp. N3 was grown in a mineral medium containing $0.5 \%$ of sunflower oil, the hydrolysis products were diglycerides, monoglycerides and free fatty acids. Moreover, the mixed culture was consuming these hydrolysis products during cultivation at $30^{\circ} \mathrm{C}$. Investigation of lard biodegradation in black soil showed that a mixed culture of strains E. aerogenes E13 and Arthrobacter sp. $\mathrm{N} 3$ degraded lard about 7 times more intensively than indigenous soil microorganisms (after six weeks of degradation in black soil, the concentration of lard was reduced by 87.5 and $8.0 \%$, respectively). Therefore, the mixed culture of strains E. aerogenes E13 and Arthrobacter sp. N3 may be used for an effective grease waste reduction in a complex cleaning technology.
\end{abstract}

Key words: fat degradation, Enterobacter, Arthrobacter, lipase

Abbreviations: FOGs, fats, oils and greases; COD, chemical oxygen demand; TLC, thin layer chromatography; LCFA, long chain fatty acid

\section{INTRODUCTION}

Fats, oils and greases (FOGs) are released into the environment with wastewater derived from the food processing industry, restaurants and kitchens or by accidental spills of oils. If not treated, they provoke an environmental effect similar to that of petroleum oil due to common physical properties. In natural environments, FOGs result in coating of animals and plants with oil, reduction of oxygen transfer rate and a high chemical oxygen demand (COD) in wastewater [1]. On the other hand, accumulation of FOGs in wastewater collection and handling systems leads to clog-

\footnotetext{
${ }^{*}$ Corresponding author. E-mail: cipinyte@biocentras.lt
}

ging of drainpipes, appearance of unpleasant odour and corrosion of sewer pipes [2].

The main constituents of FOGs are animal fats and vegetable oils. They also comprise a combination of glycerol and free fatty acids whenever hydrolysis has taken place [3]. When FOGs are spread in ecosystems, they may be used by indigenous lipid-degrading microorganism as an additional source of carbon and energy.

Many microorganisms capable of degrading FOGs have been isolated from soil and water samples. For example, studies carried by Ruiz et al. [4] have shown that nearly half of 724 strains isolated from soil rich in organic matter degraded olive oil and tributyrin, and the most active strain belonged to the genus Bacillus. Other genera of 
bacteria, such as Pseudomonas, Burkholderia, Acinetobacter, Escherichia, and fungi (Candida, Rhodotorula, Yarrowia) are known to have the ability to degrade contaminants as well as Bacillus [5-11]. However, the natural microbial degradation of FOGs is slow due to their low lipolytic activity. Furthermore, the biodegradation of lipids is often limited by the antimicrobial effect of hydrolysis products such as long-chain fatty acids $[2,3]$.

Selection of microorganisms with a high degradation activity for FOGs and their application for the removal of pollutants is one of the ways to enhance biodegradation. There are reports and patents on the use of active lipiddegrading microorganisms, particularly mixed cultures, developed in laboratory for the biological removal of FOGs $[5,11-15]$. The aerobic degradation of FOGs in wastewater by active microbial cultures is a common and one of the most efficient practices of biological treatment. However, biodegradation is rather slow and insufficient when wastewater is highly polluted by FOGs. Another alternative method to deal with a high fat content in wastewater is mechanical separation of fatty wastes from aqueous systems and their ex situ biodegradation in soil by composting or other biological treatment [15]. Moreover, ex situ biodegradation can be applicable for microbial destruction of food residuals rich in oil and grease.

Recently, increasing attention has been focused on the hydrocarbon-degrading microorganisms that have lipolytic activity [16-19]. For instance, Domenico et al. [18] have investigated diesel oil degrading bacteria isolated from Antarctic seawater and found that $90 \%$ of the isolates had grown on both diesel oil and Tween 80 . As noticed by Margesin et al. [16], the ability of microorganisms to degrade hydrocarbons and lipids is related to the fact that similar enzymes are involved in both degradation processes. In general, the initial step of hydrocarbons oxidation gives primary alcohols further converted to the corresponding fatty acids which are metabolized through the $\beta$-oxidation pathway, just as fatty acids derived from triglycerides after the hydrolytic action of lipolytic enzymes [17, 20]. Therefore, application of microbial cultures with a high hydrolytic activity toward fats and petroleum hydrocarbons could improve the biological treatment of the environment, particularly of wastewater polluted by FOGs and mineral oil.

In previous works, we have studied hydrocarbon degrading bacteria and their application for cleaning the environment from petroleum contamination. We have found that hydrocarbon-degrading bacteria belonging to the genus Arthrobacter degraded a mixture of fuel oil and diesel fuel more rapidly when grown in a complex nutrient medium containing sunflower oil or oleic acid [21,22]. So, these results lead to the presumption that our hydrocarbondegrading bacteria might be applicable for removing not only hydrocarbon but also FOGs.
The aim of this study was to select lipidic compounds degrading microorganisms and to develop a microbial composition applicable to a complex technology for grease waste utilization. In particular, microorganisms isolated from an environment contaminated with fats and bacteria applicable for removal of hydrocarbons were tested for their ability to degrade animal fats, vegetable oils, triglycerides and fatty acids and for lipase activity. Furthermore, the effect of a mixture of lipid-degrading microorganisms on removing fats from aqueous and soil environments was investigated.

\section{MATERIALS AND METHODS}

A total of 124 microbial cultures obtained from the culture collection of JSC "Biocentras" and isolated from the environment polluted with various lipids were examined.

Nutrient agar (Oxoid, Basingstoke, UK) was used for plating microbial strains, and nutrient broth (Oxoid, Basingstoke, UK) was used for the subculture and preculture of the strains. The enrichment medium composed of $1 \mathrm{~g} / \mathrm{l}$ sunflower oil, $0.5 \mathrm{~g} / \mathrm{l} \mathrm{KH_{2 }} \mathrm{PO}_{4}, 0.5 \mathrm{~g} / \mathrm{l}\left(\mathrm{NH}_{4}\right)_{2} \mathrm{SO}_{4}, 0.1 \mathrm{~g} / \mathrm{l}$ $\mathrm{MgSO}_{4}, 0.1 \mathrm{~g} / \mathrm{l} \mathrm{CaCl}_{2}$ and $1 \mathrm{~g} / \mathrm{l}$ of yeast was used to enrich lipid-degrading microorganisms. Tween-peptone agar containing $10.0 \mathrm{~g} / \mathrm{l}$ peptone, $5.0 \mathrm{~g} / \mathrm{l} \mathrm{NaCl}, 0.1 \mathrm{~g} / \mathrm{l} \mathrm{CaCl}_{2} 5 \mathrm{ml} / \mathrm{l}$ Tween 80 and $18 \mathrm{~g} / \mathrm{l}$ agar was used for the screening of lipid-degrading microbes [23]. To investigate the ability of the strains to degrade fatty substrates, a mineral medium was used. The mineral medium had the following composition: $0.5 \mathrm{~g} / \mathrm{l} \mathrm{KH} \mathrm{PO}_{4}, 0.5 \mathrm{~g} / \mathrm{l}\left(\mathrm{NH}_{4}\right)_{2} \mathrm{SO}_{4}, 0.1 \mathrm{~g} / \mathrm{MgSO}_{4}$ and $0.1 \mathrm{~g} / \mathrm{l}$ $\mathrm{CaCl}_{2}(\mathrm{pH} 6.8)$.

For flask cultures, $750 \mathrm{ml}$ Erlenmeyer flasks containing $100 \mathrm{ml}$ of nutrient broth, enrichment or the mineral medium and $10 \%$ of submerged cultures grown in nutrient broth were applied for inoculation.

For isolation of lipid-degrading microorganisms, a suspension of $1 \%(\mathrm{w} / \mathrm{v})$ soil or wastewater samples was incubated in an enrichment medium at $30^{\circ} \mathrm{C}$ and $200 \mathrm{rpm}$ for $72 \mathrm{~h}$. After the incubation, microbial cultures were plated on nutrient agar for single colony isolation. Subsequently, strains isolated and obtained from culture collection were plated on Tween-peptone agar and incubated at $30{ }^{\circ} \mathrm{C}$ for $72 \mathrm{~h}$ for screening of lipid-degrading microbes. Strains that showed an opaque halo around the colonies were selected for further experiments.

The ability of strains to degrade fatty substrates was investigated in a mineral medium supplemented with $0.1 \%$ of vegetable oil (olive and sunflower), animal fats (lard and tallow), triglycerides (tripalmitin, tristearin, triolein and trilanolein) and fatty acids (oleic, linoleic, palmitic and stearic). Inoculated and blank flasks were incubated at $30^{\circ} \mathrm{C}, 200 \mathrm{rpm}$ for $24 \mathrm{~h}$. The degradation intensity of the fats was calculated by comparing the content of residual 
fats in experimental and blank flasks. All experiments were carried out in triplicate.

The best fat degraders were tested for their capability of degrading fats in a mixed culture. For the analysis of their ability to degrade fats in an aqueous environment, cultivation was carried out under sterile conditions in $2000 \mathrm{ml}$ flasks with $500 \mathrm{ml}$ of mineral medium supplemented with $0.5 \%$ of sunflower oil on a rotary shaker at $30{ }^{\circ} \mathrm{C}$ and $200 \mathrm{rpm}$. During the cultivation, samples were taken at appropriate time intervals for the analysis of cell growth, oil degradation and lipase activity. Fat biodegradation by a mixed bacterial culture in soil was investigated under nonsterile conditions in plastic boxes filled with $100 \mathrm{~g}$ of black soil artificially polluted with $2.0 \%$ of lard. Lard-contaminated soil in experimental and blank (non-inoculated) boxes was incubated at $30{ }^{\circ} \mathrm{C}$, soil was periodically mixed, and moisture was kept at 15-20\%.

Cell count was determined by plating serial dilutions of samples on nutrient agar plates and incubating at $30^{\circ} \mathrm{C}$ for $24 \mathrm{~h}$.

After biodegradation, fat substrates were extracted from experimental and blank flasks with tetrachlormethane. The content of fat substrates was determined by IR-spectrophotometry at $2930 \mathrm{~cm}^{-1}[24]$.

To determine sunflower oil degradation products, thin layer chromatography (TLC) was carried out. The residual oil and the degradation products were extracted from the culture liquid with hexane. TLC was performed using glass silica gel plates (Fluka), with a mobile phase of hexane, diethyl ether and acetic acid $(70: 28: 2, \mathrm{v} / \mathrm{v} / \mathrm{v})$. The spots of oil and hydrolysis products were visualized by saturated iodine steam.

Lipase activity was measured by the spectrophotometric method using p-nitrophenyl palmitate as a substrate [25] as follows. An appropriately diluted submerged culture $(0.2 \mathrm{ml})$ was added to $1.8 \mathrm{ml}$ of the substrate solution prepared by mixing one part of solution A (40 mg of p-nitrophenol dissolved in $12 \mathrm{ml}$ of 2-propanol) with 19 parts of solution B (50 mM Sorensen's phosphate buffer $\mathrm{pH}=8.0$ with $0.2 \%$ sodium deoxicholate and $0.1 \%$ gum arabic). The reaction mixture was incubated at $40{ }^{\circ} \mathrm{C}$ for 3-5 min, and the substrate hydrolysis was determined by measuring the increase in absorbance at $400 \mathrm{~nm}$. One unit of lipase activity was defined as the amount of enzyme that released $1 \mu \mathrm{mol}$ of p-nitrophenol per minute under the assay conditions described.

Calculations were performed with Origin software. Experimental results were expressed as the arithmetic mean \pm standard deviation.

\section{RESULTS AND DISCUSSION}

The lipid-degrading capability of 52 petroleum hydrocarbons and greases degrading microbial cultures obtained from the culture collection of JSC "Biocentras" and 72 strains isolated from wastewater and solid wastes contaminated by FOGs were initially tested on Tween-80 peptone agar. Twenty-six strains which formed opaque zones around microbial colonies, indicating lipolytic activity, were selected. Subsequently, the fat degradation ability of the selected strains was investigated in a mineral medium supplemented with $0.1 \%$ of animal fats and vegetable oils. Five strains (UP2, N3, KL1, E13 and F2) were found to degrade all test fats at the highest rate. During $24 \mathrm{~h}$ of cultivation, the strains degraded $24.9-42.3 \%$ of tallow, $25.9-45.7 \%$ of lard, $38.4-56.6 \%$ of sunflower oil and $40.3-58.9 \%$ of olive oil. The strains were selected for further investigations.

When the environment is being contaminated by fats for a prolonged period, indigenous microorganisms can break them down and induce accumulation of long-chain fatty acids (LCFA), including palmitic, stearic and oleic acids, which form $75-90 \%$ of those present [2]. There are only a few studies concerning the aerobic degradation of fatty acids; the more common practice is anaerobic digestion [2, $3,14]$. In addition, LCFA have been reported to inhibit the activity of various microorganisms [3]. Therefore, it was interesting to investigate the ability of the selected strains to degrade saturated (palmitic and stearic) and unsaturated (oleic and linoleic) fatty acids and triglycerides containing

Ta ble. Effect of microbial strain on degradation of fatty acids and triglycerides

\begin{tabular}{|c|c|c|c|c|c|}
\hline \multirow{2}{*}{ Substrate } & \multicolumn{5}{|c|}{ Degradation (\%) by strain: } \\
\hline & E13 & F2 & UP2 & N3 & KI1 \\
\hline Oleic acid & $95.0 \pm 1.55$ & $78.3 \pm 2.33$ & $90.0 \pm 5.22$ & $95.2 \pm 2.72$ & $65.5 \pm 4.21$ \\
\hline Linoleic acid & $94.3 \pm 1.27$ & $95.7 \pm 2.03$ & $95.7 \pm 1.37$ & $92.3 \pm 3.74$ & $87.1 \pm 5.19$ \\
\hline Stearic acid & $28.5 \pm 1.05$ & $16.5 \pm 1.56$ & $17.5 \pm 1.02$ & $29.3 \pm 1.47$ & $11.3 \pm 1.05$ \\
\hline Palmitic acid & $31.2 \pm 2.50$ & $12.7 \pm 2.20$ & $19.0 \pm 0.58$ & $30.1 \pm 2.26$ & $17.0 \pm 0.95$ \\
\hline Triolein & $87.8 \pm 4.00$ & $51.0 \pm 2.50$ & $59.3 \pm 2.93$ & $65.9 \pm 3.14$ & $35.2 \pm 1.73$ \\
\hline Trilinolein & $95.5 \pm 3.92$ & $93.0 \pm 2.93$ & $67.0 \pm 3.47$ & $98.3 \pm 1.15$ & $59.5 \pm 6.44$ \\
\hline Tristearin & $41.9 \pm 2.55$ & $6.0 \pm 0.22$ & $13.0 \pm 1.15$ & $40.3 \pm 3.10$ & $10.3 \pm 0.86$ \\
\hline Tripalmitin & $23.0 \pm 1.47$ & 0 & $8.4 \pm 0.72$ & $15.9 \pm 0.99$ & $2.0 \pm 0.4$ \\
\hline
\end{tabular}


these acids under aerobic conditions. As is seen in Table, all test strains degraded unsaturated fatty acids and the corresponding triglycerides more intensively than saturated. For example, unsaturated and saturated fatty acids were biodegraded 65.5-95.7 and 11.3-31.2\%, respectively, and the corresponding triglycerides were degraded 35.2-98.3 and $2.0-41.9 \%$, respectively. Strains E13 and N3 showed the highest rates of degradation of the test fatty acids and triglycerides after $24 \mathrm{~h}$ of cultivation.

In general, liquid lipidic compounds (vegetable oils, unsaturated fatty acids and triglycerides containing these fatty acids) whose melting point is lower than the experimental temperature were more preferred by the examined microbes. In case of solid lipidic compounds, when added to the mineral medium, they formed irregular clumps which were less available for microbial and enzymatic attack. Therefore, a complete degradation of solid lipids by microbial cultures needs more time. These results are similar to those reported by other authors $[1,9]$ who have found the biodegradation rate to depend on the physical state of lipids.

At the initial stage of FOGs biodegradation microbes usually secrete extracellular lipases which hydrolyze the ester bond of glycerides into glycerol and free fatty acids [7]. The low lipolytic activity of microbial cultures can result in slow processes of the biological removal of FOGs. Therefore, to further analyse lipid degradation by the selected five strains, the time course of lipase production was investigated (Fig. 1). The results indicated that lipase activity of all microbial cultures increased during cultivation. Strain E13 showed the highest lipase activity not only after $8 \mathrm{~h}$ of cultivation, but also after $48 \mathrm{~h}(0.32 \pm 0.0015$ and $0.45 \pm 0.022 \mathrm{U} / \mathrm{ml}$, respectively). If to compare the lipase activity of strains E13 and N3, the activity of strain $\mathrm{N} 3$ was lower in the beginning of the cultivation, while after $48 \mathrm{~h}$ it was close $(0.41 \pm 0.019 \mathrm{U} / \mathrm{ml})$ to the activity of strain E13.

Strains E13 and N3, degrading lipidic compounds intensively and being the most active lipolytic strains, were chosen for further studies. The strains were obtained from the culture collection of JSC "Biocentras". They had been previously identified using the criteria of Bergey's Manual of Determinative Bacteriology [26] as Enterobacter aerogenes E13 and Arthrobacter sp. N3. It is worth mentioning that in our previous works we selected Arthrobacter sp. N3 strain as an active hydrocarbon degrader which is used for cleaning the environment from petroleum pollutants [21,22].

To assess the strains' application for the bioremediation of lipid-contaminated environments, a mixed culture of strains E. aerogenes E13 and Arthrobacter sp. N3 was grown in both aqueous (mineral medium containing $0.5 \%$ of sunflower oil) and solid (black soil with $2.0 \%$ of lard) systems. The mixed culture of the selected strains was chosen for the experiment based on our previous studies [21] and reports of other researchers $[9,13]$, indicating that mixed microbial cultures have a higher biodegradation potential than single strains.

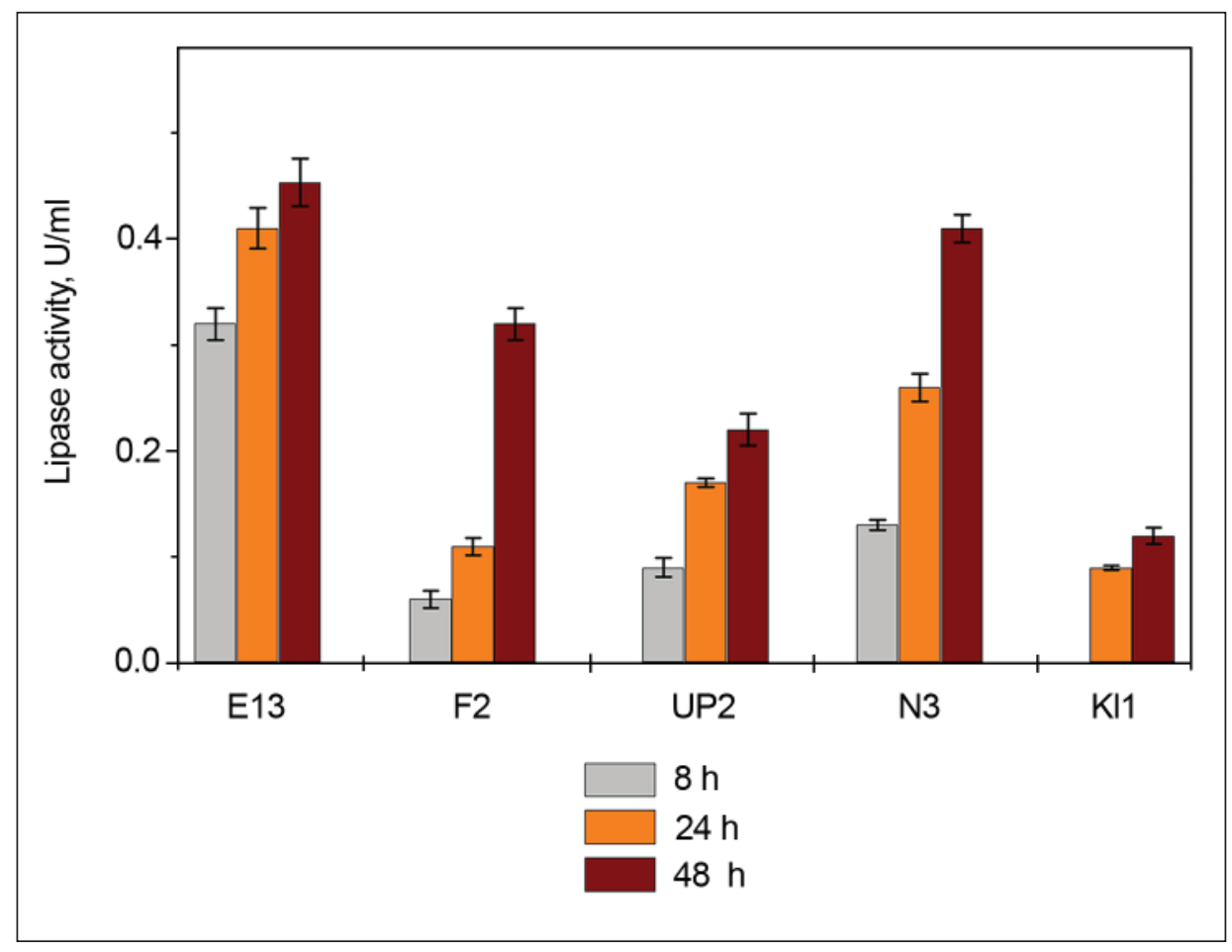

Fig. 1. Comparison of lipase activity of fat-degrading microorganisms 


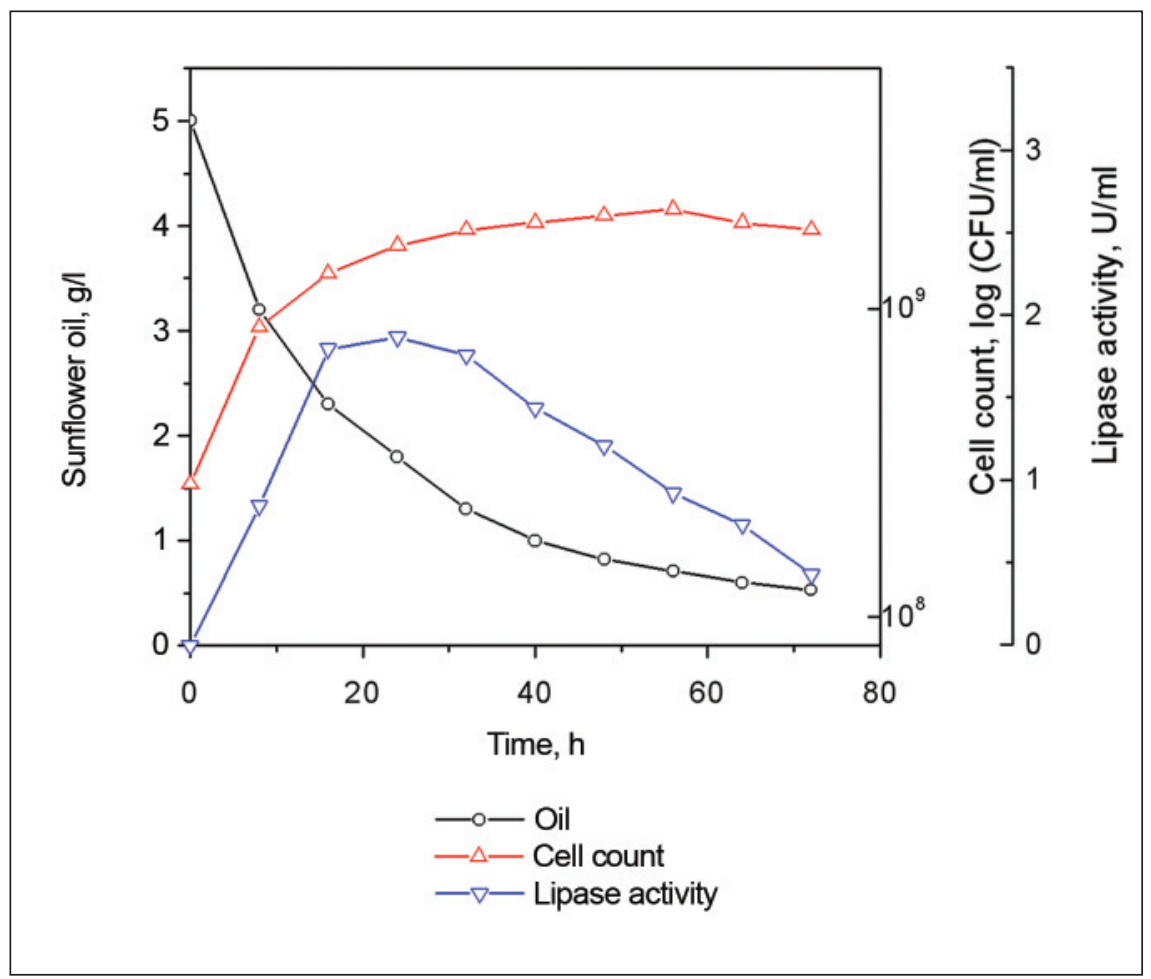

Fig. 2. Dynamics of cell number, sunflower oil concentration and lipase activity during cultivation of mixed culture of strains E. aerogenes E13 and Arthrobacter sp. N3 in mineral medium with sunflower oil

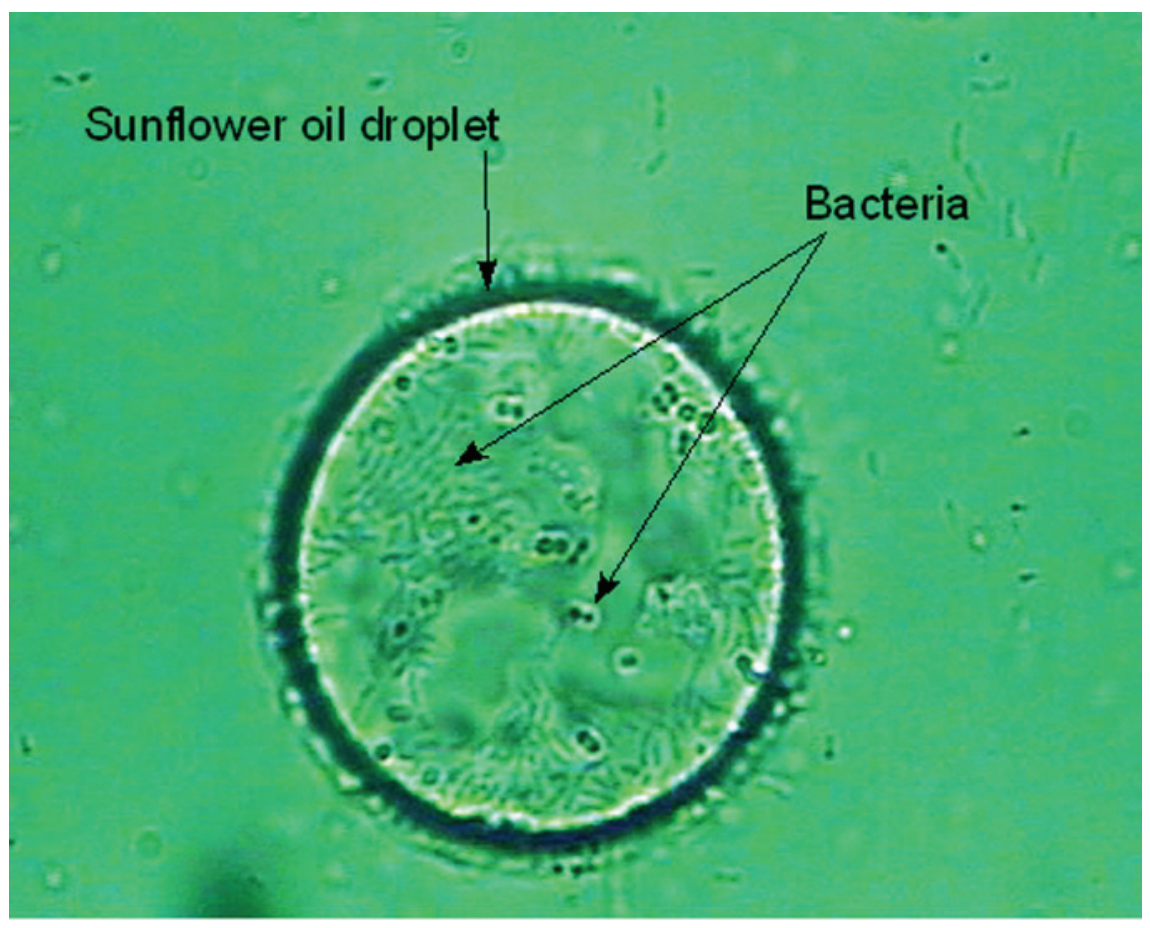

Fig. 3. Interaction between bacteria and sunflower oil in mixed culture of strains E. aerogenes $\mathrm{E} 13$ and Arthrobacter sp. N3 grown in mineral medium supplemented with $0.5 \%$ of sunflower oil 


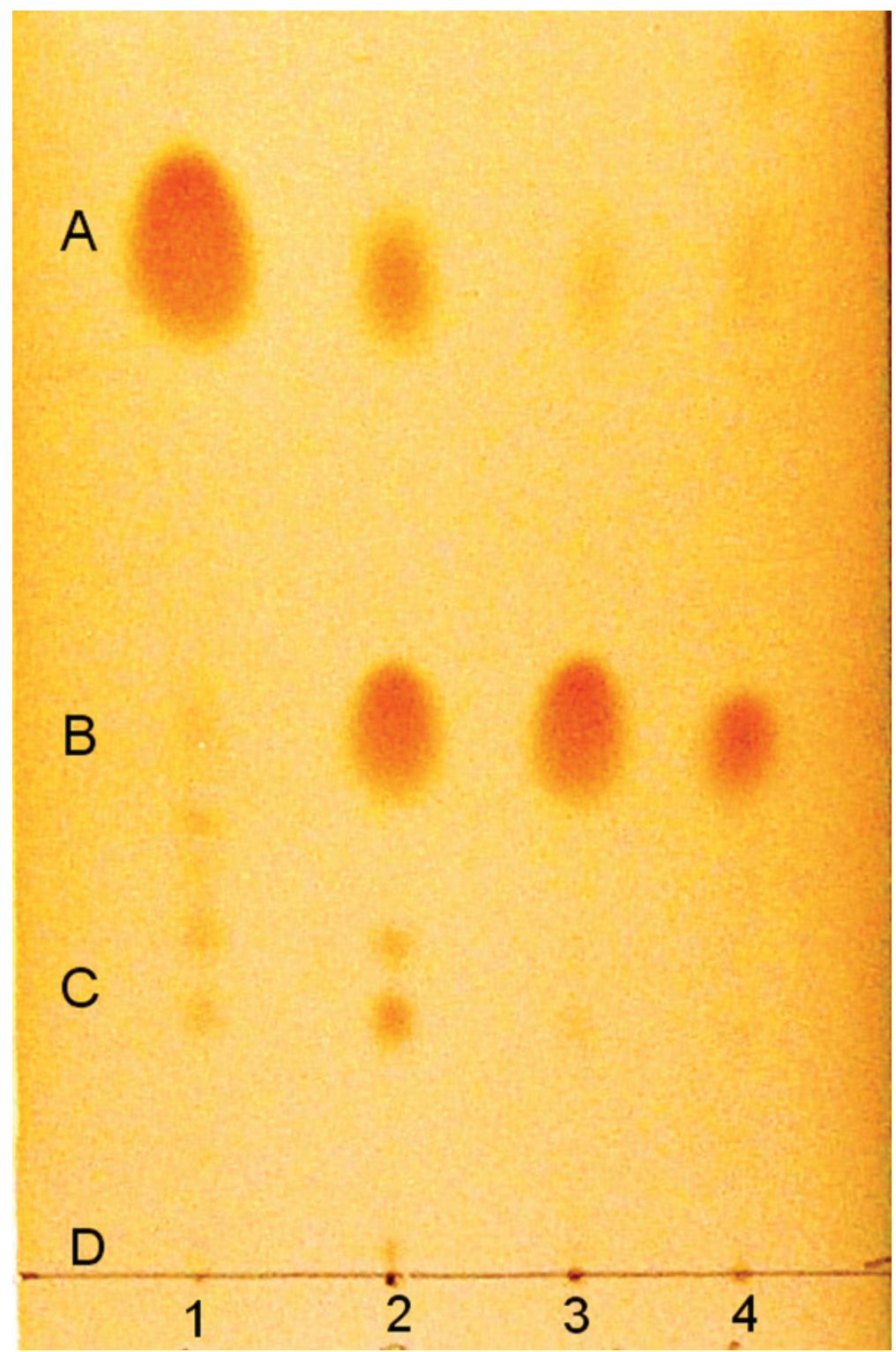

Fig. 4. Thin-layer chromatogram of products obtained after sunflower oil biodegradation by a mixed culture of strains E. aerogenes E13 and Arthrobacter sp. N3. Line 1- $0 \mathrm{~h} ; 2-24 \mathrm{~h} ; 3-48 \mathrm{~h}$; 4- $72 \mathrm{~h}$; A - triglycerides, B - fatty acids, C - diglycerides, D - monoglycerides

With a mixed culture cultivated in a mineral medium supplemented with sunflower oil under sterile conditions (Fig. 2), the most intensive reduction of the substrate was observed after $8 \mathrm{~h}$ of cultivation. Then biodegradation gradually slowed down; however, after $72 \mathrm{~h}$ of degradation by the mixed culture, the concentration of sunflower oil decreased from the initial value of 5.0 to $0.52 \mathrm{~g} / \mathrm{l}(90 \%$ of oil was degraded). Similarly to sunflower degradation rate, the most intensive increase in bacterial cell number (about 3 times) was detected during the first 8 hours of cultivation. The maximum cell count $\left(2.1 \cdot 10^{9} \mathrm{CFU} / \mathrm{ml}\right)$ was reached at $56 \mathrm{~h}$, and later the microbial population slightly decreased. In addition, the mixed culture of strains E. aerogenes E13 and Arthrobacter sp. N3 dispersed sunflower oil in the mineral medium by producing fine oil droplets and subsequently colonised them (Fig. 3). The dispersion of sunflower oil may be related to the biosurfactants produced by the strains under study. According to the report of Matsumiya et al. [5], emulsification with biosurfactants increases the interaction between microbial enzymes and lipids and thus enhances lipid degradation ability. As shown in Fig. 2, lipase activity rapidly increased during $16 \mathrm{~h}$ of the mixed culture cultivation and was more than 3 times higher compared with the activity of the strains grown separately in the nutrient medium without fats for $48 \mathrm{~h}$ (Fig. 1). The maximum lipase activity 


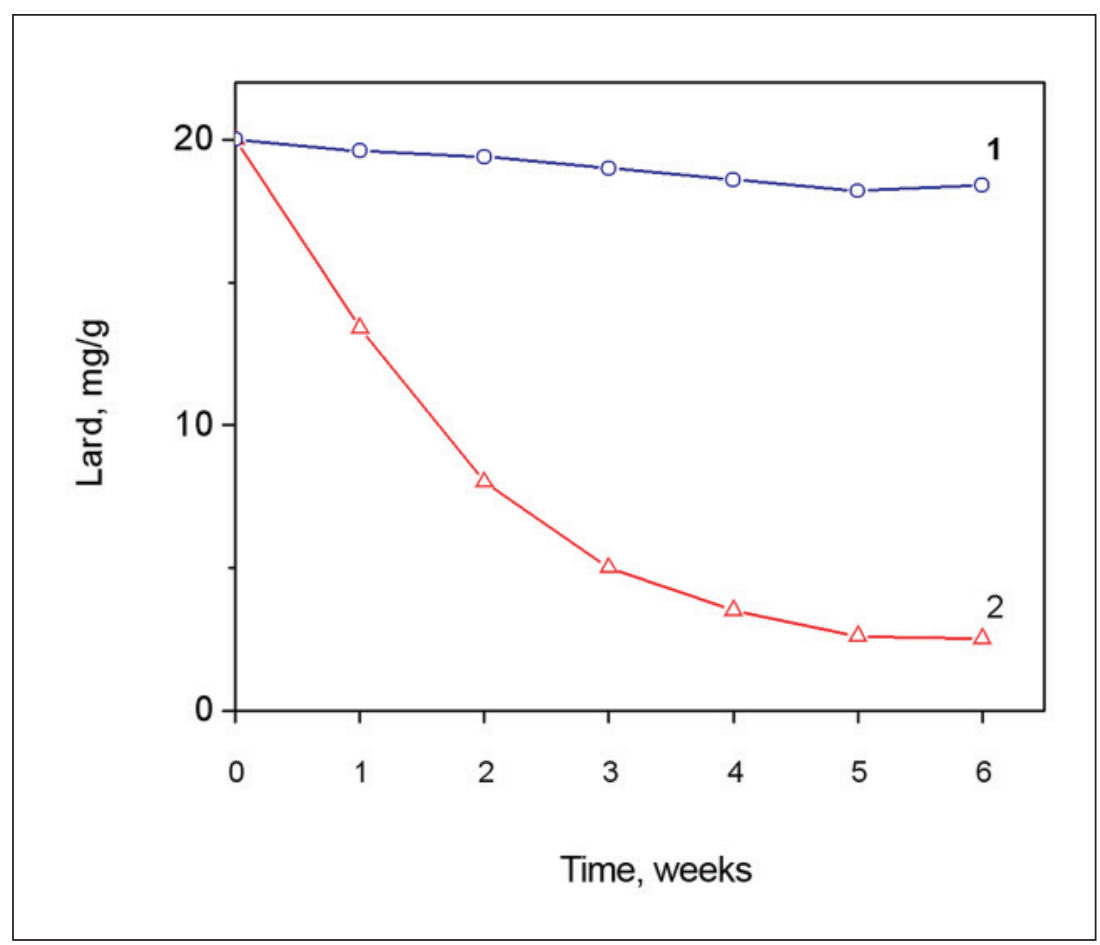

Fig. 5. Degradation of lard in black soil with a mixed culture of strains E. aerogenes E13 and Arthrobacter sp. N3. 1 - indigenous microbes (control), 2 - mixed culture of strains E. aerogenes E13 and Arthrobacter sp. N3

$(1.87 \mathrm{U} / \mathrm{ml})$ was detected after $24 \mathrm{~h}$, and then it continuously decreased. It is obvious that the high lipase production during the first $24 \mathrm{~h}$ of cultivation resulted in an intensive hydrolysis of sunflower oil (Fig. 4). After $24 \mathrm{~h}$ of cultivation, sunflower biodegradation products were free fatty acids, monoglycerides and diglycerides. Later, the glycerides were hydrolysed to fatty acids which were also metabolized by the bacterial cultures.

Overall, in the final phase of the investigation, the decrease in the number of bacteria as well as in biodegradation rate and lipase activity may be explained by the substrate depletion, the inhibitory effect of the metabolites and a remarkable $\mathrm{pH}$ decline. The medium $\mathrm{pH}$ decreased even to a value of 3.8 after $72 \mathrm{~h}$ of cultivation. A similar correlation between the acidification of the medium and lipid degradation rate was reported in the literature [10]. The authors suggested that changing the medium buffering capacity and $\mathrm{pH}$ control would be required for an effective lipid degradation by bacteria.

Fat degrading microorganisms sometimes lose their ability to degrade fats in open treatment systems due to the effects of indigenous microorganisms [5]. For the practical application of the bacterial mixture to FOG-contaminated environment treatment, lard biodegradation by a bacterial mixture was investigated under non-sterile conditions; the results are presented in Fig. 5. As is seen from the lard degradation profile, in the first two weeks of the investigation the reduction of lard concentration was most intensive and had an almost linear character. During this period, a mixed culture of E. aerogenes E13 and Arthrobacter sp. N3 strains utilized about $60.0 \%$ of the lard added. Later, the rate of lard degradation in soil gradually got slower, similarly to the sunflower oil degradation by a mixed culture in an aqueous medium; however, after six weeks the concentration of lard in samples treated with the mixed culture was reduced to $2.5 \mathrm{mg} / \mathrm{g}$, i. e. $87.5 \%$ of the lard was degraded. In comparison, indigenous soil microorganisms degraded only $8.0 \%$ of lard during the same period. Therefore, treatment with a mixed culture of strains E. aerogenes E13 and Arthrobacter sp. N3 enhanced lard removal from soil about seven times.

Our experimental results indicate that the selected mixed culture of strains E. aerogenes E13 and Arthrobacter sp. N3 actively degraded vegetable and animal fats in both aqueous and solid systems. So, bacterial strains can be regarded as effective biological agents applicable to cleaning the environment contaminated with FOGs. Moreover, a mixed bacterial culture can be used for the treatment of environments simultaneously contaminated by lipids and petroleum hydrocarbons, since Arthrobacter sp. N3 strain is also known as an active petroleum hydrocarbon degrading bacterium [22]. 


\section{CONCLUSIONS}

1. A total of 124 microorganisms were screened for the ability to degrade lipidic compounds. Strains UP2, F2, E13, K11 and $\mathrm{N} 3$ were found to degrade sunflower and olive oil, lard and tallow most intensively.

2. Strains UP2, F2, E13, K11 and N3 were studied for lipase activity and for the capability of degrading saturated (palmitic and stearic) and unsaturated (oleic and linoleic) fatty acids and triglycerides formed from the acids. Strains E13 and N3 showed the highest lipase activity and degradation rates. The strains were identified as Enterobacter aerogenes E13 and Arthrobacter sp. N3.

3. Sunflower oil degradation by a mixed culture of E. aerogenes E13 and Arthrobacter sp. N3 strains was investigated in a mineral medium supplemented with $0.5 \%$ of oil. The results of the investigation showed that sunflower oil degradation products were free fatty acids, monoglycerides and diglycerides which were consumed during the cultivation.

4. The results of lard degradation in black soil by a mixed culture of E. aerogenes E13 and Arthrobacter sp. N3 strains indicated that the mixed bacterial culture enhanced lard biodegradation about 7 times in comparison with indigenous soil microorganisms.

5. A mixed culture of E. aerogenes E13 and Arthrobacter sp. N3 strains may be used for an effective reduction of FOGs in a complex cleaning technology.

\section{ACKNOWLEDGEMENTS}

This research is related to the Eureka project E!3726 supported by the Agency for International Science and Technology Development Programmes in Lithuania.

Received 11 August 2009 Accepted 3 November 2009

\section{References}

1. Al-Darbi MM, Saeed NO, Islam MR, Lee K. Energy Sources 2005; 27: 19-34.

2. Gray NF. Biology of wastewater treatment. Oxford University Press, 1989: 6-38.

3. Cammarota MC, Freire DMG. Bioresour Technol 2006; 97: 2195-210.

4. Ruiz C, Pastor FIJ, Diaz P. Lett Appl Microbiol 2005; 40: $218-27$.

5. Matsumiya Y, Wakita D, Kimura A et al. J Biosci Bioeng 2007; 103(4): 323-30.

6. Shong HK, Dan T, Kwon DY et al. J Microbiol Biotechnol 2002; 12(4): 583-91.
7. Hasanuzzaman M, Umadhay-Briones $\mathrm{K}$, Zsiros S et al. Curr Microbiol 2004; 49: 108-14.

8. Suzuki T, Nakayama T, Kurihara T et al. J Biosci Bioeng 2001; 92 (2): 144-8.

9. El-Bestawy E, El-Masry MH, El-Adl NE. World J Microbiol Biotechnol 2005; 21: 815-22.

10. Sugimori D, Nakamura M, Mihara Y. Biosci Biotechnol Biochem 2002; 66(7): 1579-82.

11. Horakova D, Horak R, Nemec M. US patent 6059963 , 2000.

12. Brooksbank AM, Latchford JW, Mudge SM. World J Microbiol Biotechnol 2007; 23: 977-85.

13. Bhumibhamon O, Phattayakorn K. Kasetsart J 2003; 37 : 323-33.

14. Tisinger JL, Drahos DJ, Leder J, Paone DA. US patent 0049832, 2003.

15. Lemus GR, Lau AK. Can Biosystems Eng 2002; 44: 33-39.

16. Margesin R, Labbe D, Schinner F et al. Appl Environ Microbiol 2003; 69(6): 3085-92.

17. Margesin R, Schinner F. Appl Environ Microbiol 2001; 67(7): 3127-33.

18. Domenico M, Guidice A, Michaud L et al. Pollar Res 2004; 23(2): 141-6.

19. Giudice AL, Michaud L, Gentile G. Atti dell'Accademia Peloritana dei Pericolanti Classe di Scienze Fisiche, Matematiche e Naturali 2005; 83.

20. Whyte LG, Havari J, Zhou E et al. Appl Environl Microbiol 1998; 64(7): 2578-84.

21. Levišauskas D, Tekorius T, Čipinytė V, Grigiškis S. Latv Kim Z 2004; 1: 75-80.

22. Grigiškis S, Čipinytė V, Levišauskas D, Baškys E. Latv Kim Z 2005; 1: 68-76.

23. Aktas E, Yigit N, Ayyildiz A. Int Med Res 2002; 30: $322-4$.

24. Standard Methods for the Examination of Water and Wastewater. Washington: American Health Association, 1998; 5-37.

25. Winkler UK, Stuckmann M. J Bacteriol 1979; 138 (3): 663-70.

26. Bergey's Manual of Determinative Bacteriology. Baltimore: Williams \& Wilkins, 1994. 
Vilma Čipinytė, Saulius Grigiškis, Egidijus Baškys

\section{RIEBALUS SKAIDANČIŲ MIKROORGANIZMŲ, TINKANČIŲ APLINKAI VALYTI NUO RIEBALŲ, ATRANKA}

\section{Santrauka}

Siekiant surasti mikroorganizmus, kuriuos būtų galima pritaikyti kompleksinejje riebalinių atliekų utilizavimo technologijoje, buvo patikrintas 124 kamienu gebejjimas skaidyti riebalinius substratus. Nustatyta, kad UP2, F2, E13, K11 ir N3 kamienai greičiausiai skaidè saulègrąžų ir alyvuogių aliejų, kiaulienos taukus bei jautienos lajų, o efektyviausi buvo E13 ir N3 kamienai, kurie pasižymėjo aukščiausiu lipazès aktyvumu bei intensyviausiai skaidè sočiąsias (palmitino ir stearino) ir nesočiąsias (oleino ir linolo) riebalų rūgštis bei iš jų sudarytus trigliceridus. Šie kamienai buvo gauti iš UAB „Biocentras“ mikroorganizmų kolekcijos ir yra identifikuoti kaip Enterobacter aerogenes E13 ir Arthrobacter sp. N3. Mišrią E. aerogenes E13 ir Arthrobacter sp. N3 kamienų kultūrą auginant mineralinëje terpejje su $0,5 \%$ aliejaus nustatyti šie aliejaus hidrolizès produktai: riebalų rūgštys, monogliceridai ir digliceridai. Be to, pastebèta, kad bakterijos šiuos hidrolizès produktus naudojo augimui. Tyrimo rezultatai, gauti kiaulienos taukus juodžemyje skaidant su mišria E. aerogenes E13 ir Arthrobacter sp. N3. kamienų kultūra, rodo, kad ši mišri bakterijų kultūra riebalus skaidè apie 7 kartus intensyviau nei vietiniai dirvožemio mikroorganizmai (kiaulienos taukų koncentracija dirvožemyje per 6 savaites sumažèjo atitinkamai 87,5 ir 8,0 \%). Taigi mišrią E. aerogenes E13 ir Arthrobacter sp. N3 kamienų kultūrą galima taikyti kompleksinëje riebalinių atliekų šalinimo technologijoje.

Raktažodžiai: Enterobacter, Arthrobacter, lipazè, riebalų skaidymas 